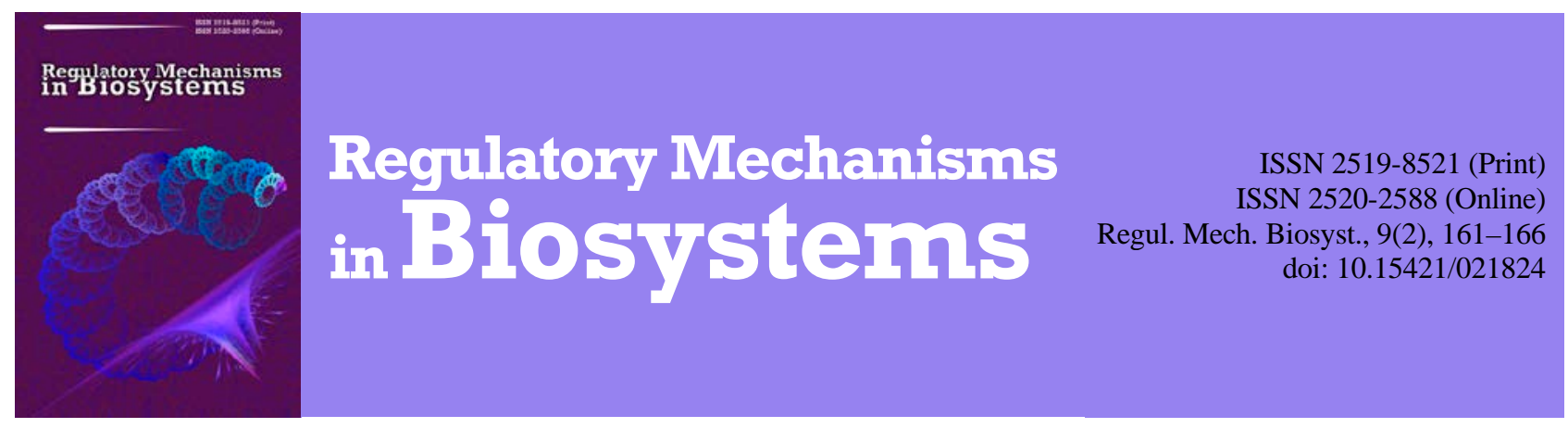

\title{
Modeling the invasiveness of Ulmus pumila in urban ecosystems in conditions of climate change
}

\author{
Y. Lykholat, N. Khromykh, O. Didur, A. Alexeyeva, T. Lykholat, V. Davydov \\ Oles Honchar Dnipro National University, Dnipro, Ukraine
}

Article info

Received 11.03.2018

Received in revised form 02.05.2018

Accepted 06.05.2018

Oles Honchar Dnipro National University, Gagarin av., 72 ,

Dnipro, 49010, Ukraine. Tel.:+38-050-229-20-48

E-mail: lykholat2006@ukr.net

\begin{abstract}
Lykholat, Y., Khromykh, N., Didur, O., Alexeyeva, A., Lykholat, T., \& Davydov, V. (2018). Modeling the invasiveness of Ulmus pumila in urban ecosystems under climate change. Regulatory Mechanisms in Biosystems, 9(2), 161-166. doi:10.15421/021824
\end{abstract}

Climatic change can influence the boundaries of the natural and alien plant species distribution. Fluctuations in air temperature, relative humidity and other factors can become a stimulus to initiation and / or intensification of the invasive nature of some adventive plant species, especially in areas with a high degree of anthropogenic transformation. This paper presents an analysis of the current state and a forecast of the invasiveness of the alien species Ulmus pumila L. (Asiatic elm) in the Northern Steppe Dnieper under conditions of climatic change. Two local U. pumila populations consisting of young different age trees were found during a route survey in the territory of the large industrial city Dnipro $\left(48^{\circ} 28^{\prime} 00^{\prime \prime} \mathrm{N}\right.$, $35^{\circ} 01^{\prime} 05^{\prime \prime} \mathrm{E}$ ) in its left-bank and right-bank parts.The seed origin of both local populations of Asiatic elm is confirmed by the fact that the young plants were spaced at a distance of 50 to $120 \mathrm{~m}$ from adult trees, which could potentially be parent plants. Both the left-bank and right-bank populations of $U$. pumila were located on abandoned construction sites, where there were numerous reinforced concrete slabs, piles and abundant construction debris. In both $U$. pumila local populations, 100 different-aged trees were randomly selected throughout the site, and their age and the morphometric parameters were measured to simulate the development process of the detected populations, provided the current trends of climate change continue. Analytical dependence of the number of trees in the left-bank local $U$. pumila population on development time was described by a polynomial model with a determination coefficient of $98.3 \%$. The graphic representation of this model had a sinusoidal character, and a similar dynamic of left-bank population growth in the subsequent years was suggested. The dynamic of the number of trees in the right-bank local Asiatic elm population was described by an exponential model with a determination coefficient of $84.4 \%$, and its graphical representation was exponential. According to the forecast, by 2020, the number of plants in the right-bank local population of U. pumila can increase 4-fold in comparison with 2015 while maintaining the current dynamic of population development. Thus, the created mathematical models adequately described the dynamics of development of both local populations during the last 15 years and predicted their subsequent intensive growth, confirming the initiation and intensification of the invasive nature of the alien species $U$. pumila by climatic change in the Steppe Dnieper.

Keywords: Asiatic elm; invasiveness; modeling; local population; climatic change

\section{Introduction}

Penetration of organisms into new territories has long acquired a global character and often provokes severe consequences for natural ecosystems, primarily, threatening the conservation of biodiversity at all levels (Blackburn et al., 2014; Dumalisile \& Somers, 2017; Fateryga \& Bagrikova, 2017; Foxcroft et al., 2017). Identification of invasive species and the ways of their introduction and spreading, implementation of measures to regulate or eradicate priority invasive species are today one of the urgent general tasks specified in a number of international documents. The European Convention on the Conservation of Wild Fauna and Flora and Natural Habitats (Berne, 1979) ratified by Ukraine in 1999, and the UN Convention on Biological Diversity (1992) ratified by Ukraine in 1994 call for the prevention of invasions, control or destruction of those alien species that threaten ecosystems, habitats, groupings and species.

In view of the above problem, the attention of researchers is attracted by the significant rate of degradation of the natural phytocenoses due to constant invasion of alien plant species in the natural communities (Pyšek and Richardson, 2006; Chytrý et al., 2009; Richardson \& Rejmánek, 2011; Vilà et al., 2011; Kowarik \& Pyšek, 2012; Pysek et al., 2012; Wagner et al., 2017). The consequences of introducing invasive plant species into phytocenoses are numerous and not only ecological (Lockwood et al., 2006; Abramova, 2012), but also economic (van Wilgen et al., 2001; Olson, 2006) and social (Pimentel et al., 2005; Olson, 2006). The economic consequences of invasions, directly caused by human economic activity, usually lead to financial losses (de Lange et al., 2010). Social consequences mainly affect human health and safety, as well as the quality of life in general (Lykholat et al., 2016); cultural heritage and other aspects of the social order (Marbuah et al., 2014). Thus, alien species damage agriculture (Pratt et al., 2017) and forestry (Borisova, 2016), negatively transform the functioning of urban ecosystems and adversely affect human health by becoming a source of allergies and other diseases (Guzzetti et al., 2017; Pismarkina \& Silaeva, 2018).

Alien species displaced by human activity beyond their native geographical range (Blackburn et al., 2014), behave differently in their new habitats. Some of the aliens quickly drop out of plant communities, others capture a significant part of the new territory, beyond which they do not or very rarely venture, others acclimatize, naturalize, displace the native species, and even take their place in the natural plant communities. Thence, invasive alien species are rightly considered the second 
most important threat to biodiversity after the destruction of habitats. Habitat transformed under the influence of invasive species creates opportunities for the manifestation of aggressive qualities of those native species that can change their range, moving northward or appearing in a favourable environment for them in the urban phytocenoses and in private plots as well. Therefore, studies of the transformation of biological diversity (Nazarenko et al., 2018) and the geography of invasions (Maslyakov \& Izhevsky, 2009; Lykholat et al., 2017; Pismarkina \& Silaeva, 2018) are critically important. One of the key aspects of study of invasions is their quantitative assessment to determine the effect of different stages of invasion from species penetration (introduction) to the time when direct environmental impact occurs (Rouget et al., 2016).

The highest concentration of alien and invasive plant species is observed in urbanized areas (Trentanovi et al., 2013; Baranova \& Bralgina, 2015; Baranovski et al., 2017), where the invasive processes manifest themselves specifically, differing from invasions in the natural communities (Gaertner et al., 2017). The variety of immigration paths for plants and their sprouts, the large number of disturbed habitats, high mobility of the human population and many similar factors lead to the fact that urbanized territories become the plots for the emergence of plant invasions and their further settlement (Fuentes et al., 2015; Lykholat et al., 2017).

Changes in the climatic conditions in the direction of increasing temperature and aridity that have occurred over the past decades have led to altered population dynamics of the native plant species (Hou et al., 2014; Bahguna \& Jagadish, 2015; Sperlich et al., 2015; Mech et al., 2018). However, climate change can affect the likelihood of alien species invading a territory, as well as their chances of naturalization. In previous studies, we established the extremely high sensitivity of the autochthonous (Lykholat et al., 2016a) and alien (Lykholat et al., 2016b) woody plant species, even to minor fluctuations in the microclimate and illumination in the Steppe Dnieper. Given the continental nature of the regional climate, one should expect that strengthening of its aridity traits may be an effective stimulus in influencing the boundaries of plant species distribution. We suggested the possibility for some plant species to gain advantages for their survival and spread in the conditions of climatic change over recentt years. To test the hypothesis, the present distribution of the alien woody plant species with an early association with artificially created habitats was investigated. The aim of this work was to identify, assess the current state and predict the dynamics of increase in the number of plants of alien tree species Ulmus pumila $\mathrm{L}$. under the conditions of climatic change.

\section{Materials and methods}

Study area. Population studies were conducted in 2017 by the field route method in the territory of the large industrial city Dnipro $\left(48^{\circ} 28^{\prime} 00^{\prime \prime} \mathrm{N}, 35^{\circ} 01^{\prime} 05^{\prime \prime} \mathrm{E}\right)$, which covers an area of $405 \mathrm{~km}^{2}$ within the geographic zone of the Northern Steppe Dnieper. The city of Dnipro is divided by the Dnieper River into the right and left parts, so two study sites were selected, respectively, in the right-bank and left-bank part of the city (Fig. 1).

Considering that most of the research on the impact of climate change on plants is focused on the effects of temperature increase (Walther et al., 2009; Bahuguna \& Jagadish, 2015), a comparative analysis of air temperature, precipitation level and number of dry days (relative humidity below $30 \%$ ) during the vegetation period of woody plants was carried out. In this paper, the analysis was based on the data of the Hydrometeorological Service in Dnipropetrovsk region. Fluctuations in temperature (Fig. 2a) and in precipitation (Fig. 2b) in the recent years have been correlated with the climatic norm, which reflects the averaged data of 50 years of observations.

Data collection. The test objects were local populations of alien woody plant species of Asiatic elm (Ulmus pumila L.),which is of Central Asian origin and was introduced into the Steppe Dnieper in the middle of the last century. This species requires a lot of sunlight, demonstrating rapid growth, and does not tolerate shading. $U$. pumila plants also are rather intolerant of wet soil conditions, preferring well-drained soils. While this species is very resistant to drought and severe cold and is able to grow on poor soils, its short period of dormancy, flowering in early spring, and subsequent continuous growth until the first autumn frosts, makes it vulnerable to the influence of cold.

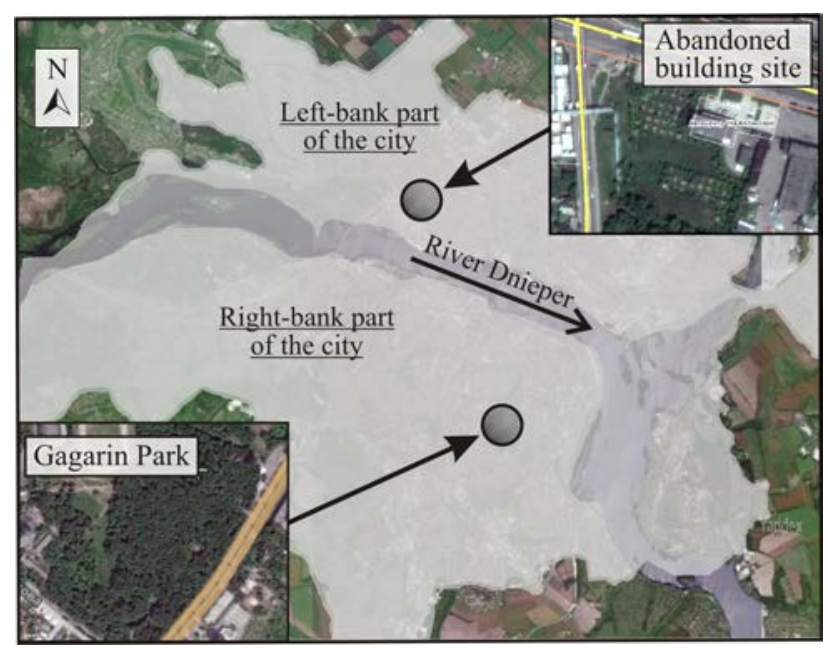

Fig. 1. Local populations of alien species Ulmus pumila L. in the city of Dnipro: $\odot$ - investigated sites in the urban areas

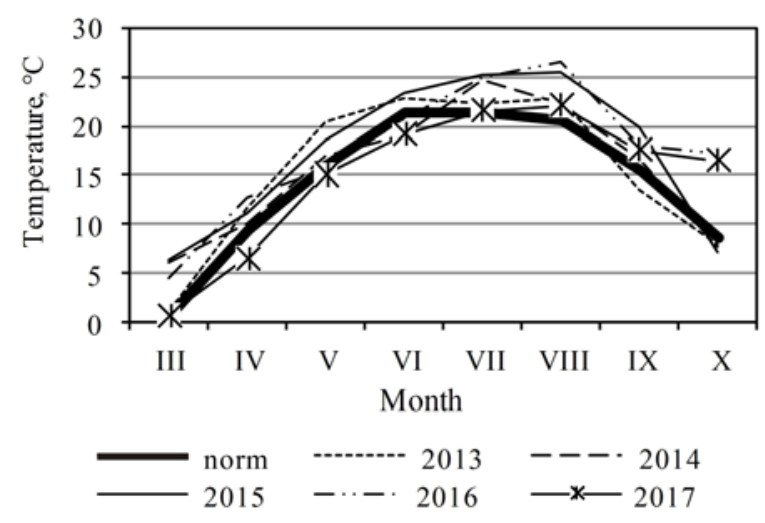

$a$

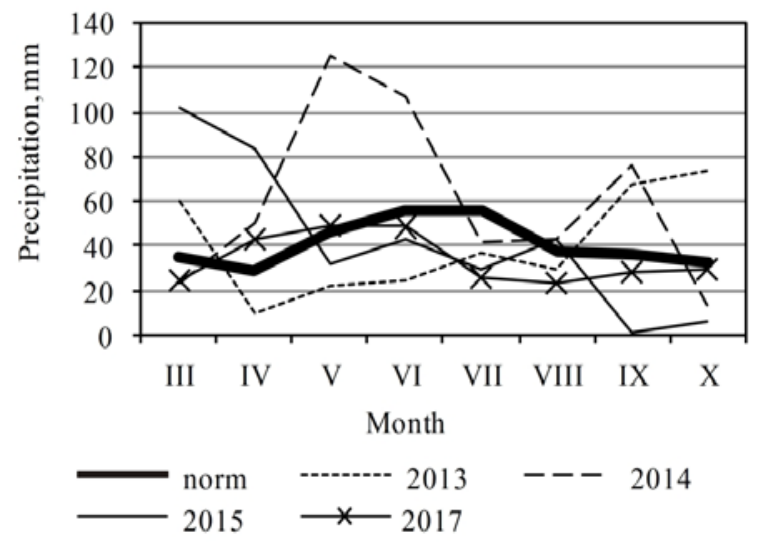

Fig. 2. Fluctuations in air temperature $(a)$ and rainfall $(b)$ relative to the climatic norm

The urban left-bank local population of $U$. pumila $\left(48^{\circ} 30^{\prime} 58.5^{\prime \prime} \mathrm{N}\right.$, $35^{\circ} 02^{\prime} 46.3^{\prime \prime} \mathrm{E}$ ) was found during a survey of an abandoned construction site on which piles were heaped and reinforced concrete construction panels were laid. The site was rectangular in shape with dimensions of $80 \times 90 \mathrm{~m}$, and it was covered with herbaceous vegetation represented by ruderal-steppe and ruderal-meadow species of plants. The pipes of the heating main were located along the two sides of the plot, and the other two sides adjoined steep slopes. The local population of $U$. pumila contained a large number of young trees of different ages, dispersed across the abandoned construction site. Adult, artificially planted plants of Asiatic elm were discovered outside the site at a distance of more than $50 \mathrm{~m}$, which indicates the seed origin of the young plants of $U$. pumila. 
The urban right-bank local population of $U$. pumila $\left(48^{\circ} 26^{\prime} 07.9^{\prime \prime}\right.$ $\mathrm{N}, 35^{\circ} 02^{\prime} 07.8^{\prime \prime} \mathrm{E}$ ) was identified on a site with unfinished construction on the territory of Gagarin Park. The size of the plot was about $80 \times 70$ $\mathrm{m}$; the original soil cover (ordinary chernozem loam moderately low humus content, or Calcic Chernozem in WRB) was anthropogenically transformed due to the laying of concrete slabs at a depth of 5 to $20 \mathrm{~cm}$, as well as due to the presence of construction debris. The different-aged young plants of Asiatic elm were spaced at a distance of 50 to $120 \mathrm{~m}$ from a single adult 50-year-old tree, which could potentially be the parent plant. This circumstance is a convincing proof of the seed origin of the local population of $U$. pumila on the plot in Gagarin Park.

In the left-bank and right-bank local populations, 100 young different-aged plants of Asiatic elm were randomly selected throughout the site. For each of $U$. pumila trees, the age, tree height, tree stem diameter at the level of $1.3 \mathrm{~m}$, as well as the diameter of the root collar of the stem were measured.

Data analysis. The invasive status of $U$. pumila was determined in accordance with the generally accepted interpretation (Blackburn et al., 2014) as the ability of the species to form the populations of seed origin at a considerable distance from the parent plants.

In modern scientific research, mathematical modeling is used to study systems of varying complexity and nature, including biological ones. Simulation is carried out to achieve one of two purposes: either to predict the behaviour of various objects, or to optimize their functioning (Zamin et al., 2013). Since the models of prediction of species propagation are standard instruments in environmental studies used to solve a number of applied and conservation-related problems (Hanspach et al., 2010), we applied a standard approach. For this, the regression analysis methods implemented in the Excel and Statgraphics Centurion space were applied. The use of regression allows us to display the relationship of two variables in an analytical expression, to select a model with the best approximation of the data, and to make a prediction about the dependent variable (Frye, 2013). In our study, a forecast was carried out on the possible growth in the number of plants in the local populations of $U$. pumila at the study sites until 2020.

\section{Results}

The local population of young $U$. pumila, found in the left-bank part of the city of Dnipro on the abandoned construction site, was represented by trees of different age status and the morphometric parameters as well (Table 1).

Table 1

Morphometric parameters of plants of the $U$. pumila left-bank local population

\begin{tabular}{ccccc}
\hline $\begin{array}{c}\text { Tree age, } \\
\text { year }\end{array}$ & $\begin{array}{c}\text { Number of } \\
\text { trees, \% of total }\end{array}$ & $\begin{array}{c}\text { Tree height, } \\
\mathrm{m}\end{array}$ & $\begin{array}{c}\text { Root collar } \\
\text { diameter, cm }\end{array}$ & $\begin{array}{c}\text { Stem diameter, } \\
\text { cm (at 1.3 m) }\end{array}$ \\
\hline 4 & 4 & $0.6-1.5$ & $0.6-2.5$ & $0.2-0.9$ \\
5 & 14 & $0.8-3.0$ & $1.3-5.5$ & $0.4-1.4$ \\
6 & 23 & $1.4-3.4$ & $1.4-4.0$ & $0.9-1.9$ \\
7 & 10 & $1.4-4.1$ & $1.2-4.5$ & $0.4-2.5$ \\
8 & 15 & $1.4-3.5$ & $2.5-6.0$ & $0.6-2.5$ \\
9 & 20 & $1.5-3.5$ & $2.5-10.0$ & $0.6-4.6$ \\
10 & 3 & $1.8-2.0$ & $3.5-5.5$ & $1.0-2.0$ \\
11 & 11 & $3.1-18.0$ & $4.0-30.0$ & $1.8-12.6$ \\
\hline
\end{tabular}

The largest part of the left-bank local population of Asiatic elm was composed of trees that are in the age range from 5 to 9 years. Morphometric indices of the young plants in the local population of $U$. pumila varied in a fairly wide range, which may reflect differences in growing conditions. Here we can talk about the unevenness of anthropogenically transformed soil conditions, the influence of the heating main and other factors. For instance, it was established that a group of young trees of $U$. pumila, represented for the most part by 11-year-old plants, grew in close proximity to concrete slabs laid on the abandoned building site (Fig. 3).

Thus, the local population of $U$. pumila young plants found on the abandoned building site in the left-bank part of the city of Dnipro had a seed origin and was formed over the last 12 to 15 years at a considerable distance from the potential parent plants, which indicates the invasive nature of the population. Since the most important stage of this study was to predict the further development of the invasiveness of alien species, the obtained results were used to create a mathematical model of the invasion process in the local populations of $U$. pumila during conditions of change the regional climatic conditions.

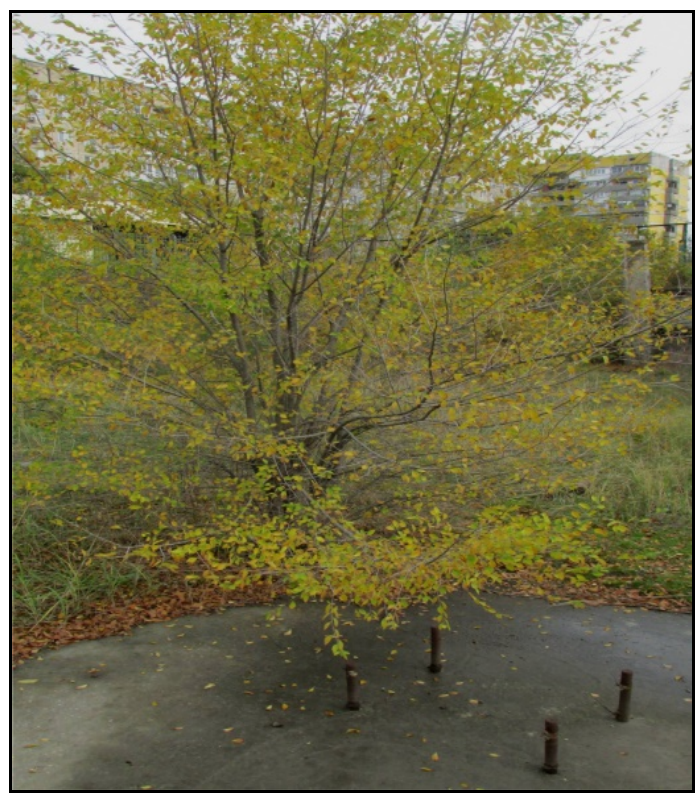

Fig. 3. Growth of the young trees of $U$. pumila in the left-bank local population

The analytical dependence of the number of young plants of $U$. pumila on the time, during which the trees in the left-bank local population had been growing on the construction site, was described by the following equation:

$$
\begin{aligned}
& y=0,1063 x^{6}-1281,8 x^{5}+6 \cdot 10^{6} x 4-2 \cdot 10^{10} x^{3}+ \\
& +3 \cdot 10^{13} x^{2}-2 \cdot 10^{16} x+7 \cdot 10^{18}\left(R^{2}=98.3 \%\right)
\end{aligned}
$$

where, $\mathrm{y}$ is the number of plants (a specimen); $\mathrm{x}$ - study period (year).

Several different types of simple regression models (linear, polynomial, and logarithmic) were created, but they had a very low degree of data approximation. Of these, the polynomial model has revealed acceptable statistical estimates that allow predicting the development of invasiveness of the alien species Asiatic elm, provided that the current trends of climate change are maintained, in particular if the air temperature rises compared to the climatic norm. The graphic representation of the proposed polynomial model of the dependence of number of the trees on the formation time of the left-bank local U. pumila population has a sinusoidal character (Fig. 4).

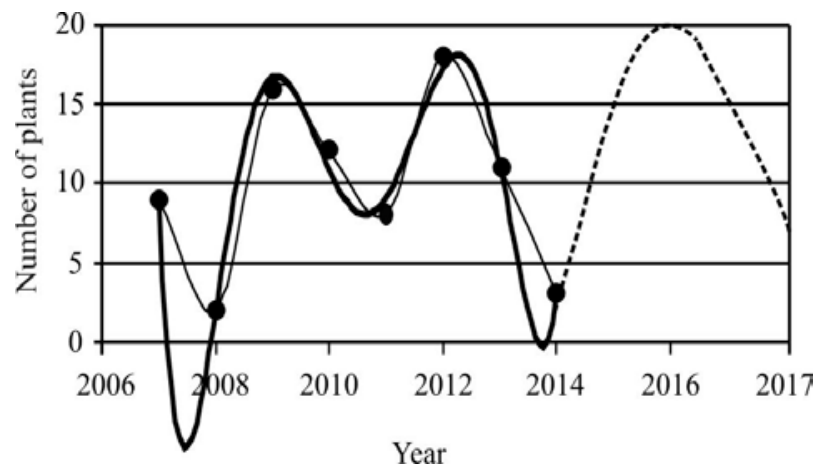

Fig. 4. Empirical and theoretical distribution of number of the trees by the years in the left-bank local population of alien species $U$. pumila: the thin solid line is empirical data, the thick line is a theoretical curve, and the discontinuous line is a predicted curve

The creation of this graphic model was based on the assumption that during the two years preceding the year of research (that is, in 2015 and 2016), the number of young plants in the left-bank local population of $U$. pumila continued to increase, in other words, the tendency to 
increase in the invasiveness of the alien species persisted. The young trees of Asiatic elm on the abandoned construction site in the right-bank part of the city of Dnipro (the territory of the Gagarin Park) formed dense thick thickets of seed origin, in which the plants' density reached a level of 11,875 pieces $\bullet \mathrm{ha}^{-1}$.

The age of the Asiatic elm young plants that formed the right-bank local population ranged from 2 to 13 years. The wide range of variability of height and stem diameter of $U$. pumila young plants was revealed during the survey of the right-bank local population in the Gagarin Park (Table 2).

Table 2

Morphometric parameters of plants in the $U$. pumila right-bank local population

\begin{tabular}{ccccc}
\hline $\begin{array}{c}\text { Tree age, } \\
\text { year }\end{array}$ & $\begin{array}{c}\text { Number of trees, } \\
\text { \% of total }\end{array}$ & $\begin{array}{c}\text { Tree } \\
\text { height, } \mathrm{m}\end{array}$ & $\begin{array}{c}\text { Root collar } \\
\text { diameter, } \mathrm{cm}\end{array}$ & $\begin{array}{c}\text { Stem diameter, } \\
\mathrm{cm}(\text { at 1.3 m) }\end{array}$ \\
\hline 2 & 10 & $2.4-5.4$ & $1.8-2.0$ & $0.4-0.6$ \\
3 & 26 & $5.1-6.9$ & $2.0-2.3$ & $0.5-0.7$ \\
4 & 10 & $6.7-9.0$ & $2.0-2.4$ & $0.6-0.9$ \\
5 & 16 & $3.2-4.9$ & $1.2-2.2$ & $0.8-1.4$ \\
6 & 10 & $6.0-7.2$ & $2.8-3.9$ & $1.2-2.0$ \\
7 & 6 & $4.0-4.6$ & $3.8-5.5$ & $2.8-4.0$ \\
8 & 5 & $6.8-7.3$ & $6.8-7.8$ & $6.8-7.3$ \\
9 & 4 & $6.2-6.5$ & $7.2-8.0$ & $6.3-6.9$ \\
10 & 4 & $6.5-6.9$ & $7.8-8.4$ & $6.8-7.5$ \\
11 & 4 & $5.7-6.6$ & $13.8-15.5$ & $9.5-11.2$ \\
12 & 3 & $9.1-9.8$ & $16.5-18.0$ & $11.5-12.6$ \\
13 & 2 & $8.9-9.3$ & $21.0-22.5$ & $12.2-12.5$ \\
\hline
\end{tabular}

Young plants aged from 3 to 5 years constituted the dominant group in the right-bank local population of Asiatic elm on the site with unfinished construction in the Gagarin Park. The obtained results testify to intensive development of the right-bank local population during the last 15 years preceding the research. The revealed dynamics of development of the young plants' local population indicates a progressive character of the population and confirms the invasive status of the alien species $U$. pumila.

The results of the study were used to create a mathematical model for the development of the right-bank local population of $U$. pumila. Various regression models were used to find the analytical expression of the dynamics of the invasive process in the local population of the alien species on the site in Gagarin Park. In comparison with other types of regression models (linear, polynomial, logarithmic, and others), the exponential model revealed acceptable statistical estimates. This model allowed us not only to get an idea of the dynamics of the number of Asiatic elm plants, but also to predict the development of invasiveness in the case of the current trends of climate change.

The analytical dependence between the number of young plants of seed origin in the right-bank local population of $U$. pumila and the time of population development was described by the following equation:

$$
y=\exp (0.266653 * x-533.977)\left(R^{2}=84.4 \%\right) \text {, }
$$

where, $y$ is the number of plants (a specimen); $\mathrm{x}$ - study period (year).

The mathematical model calculated for the right-bank local population of Asiatic elm has a high coefficient of determination (84.4\%) and adequately approximates empirical data with a significance level $(\mathrm{P}<0.001)$.

The graphic representation of the proposed model, describing the dynamics of the development of $U$. pumila local population on the site in Gagarin Park, was of an exponential nature (Fig. 5).

According to the created mathematical model, the number of the young plants of seed origin in the right-bank local population of Asiatic elm on the territory of Gagarin Park tends to increase up to 2020 inclusive. The forecast was made that in 2020 the local population of the alien species $U$. pumila on the site with unfinished construction in Gagarin Park will increase 4 times in comparison with 2015, 15 times in comparison with 2010, and more than 50 times in comparison with 2005.

\section{Discussion}

The specific feature of the Asiatic elm is that the phenological phases of tree flowering and seed formation occur in early spring, and that the seeds have a very short life span. Like recalcitrant seeds of other plant species, seeds of $U$. pumila lose their ability to germinate after a few months in the open air (Copeland \& McDonald, 2012). Consequently, the abundant appearance of $U$. pumila young plants of seed origin could be due to the favourable climatic conditions for the germination of seeds, the rapid growth of seedlings and the successful wintering of young plants. It follows that the necessary conditions for air temperature, relative humidity and other climatic factors should have been present in the area of research at a time when the local populations of $U$. pumila began to form, that is, in the last 15 years.

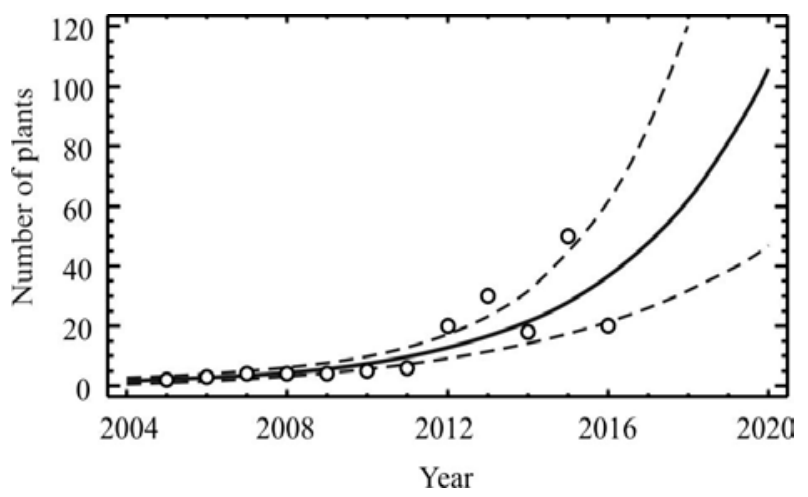

Fig. 5. Empirical and theoretical distribution of number of the trees by years in the right-bank local population of invasive alien species $U$. pumila: circles are empirical data, the thick line is a theoretical curve, and the discontinuous line is 95\% confidence interval

Analysis of temperature curves (Fig. 2a) allows us to state that over the previous years, an excess of the temperature norm was observed during the periods corresponding to the beginning and the end of the Asiatic elm plants' vegetation. It is likely that this rise in air temperature could have played a key role in initiating the invasion of alien species $U$. pumila and the formation of both local populations on the abandoned construction sites found simultaneously in two different parts of the city of Dnipro. Our conclusion is supported by the results of an experiment with 8 different species of shrubby and herbaceous plants, which showed that the most common response to the effect of warming was the acceleration of spring growth (Prieto et al., 2009).

Comparison of the graphic model of the Asiatic elm invasion process in the left-bank local population with the meteorological data given above (Fig. 2b) allowed us to conclude that the increase or decrease in the number of young plants of seed origin coincides, respectively, with the increase or decrease in the amount of precipitation during the growing season. Obviously, the functional traits of plants that determine the development dynamics of the $U$. pumila left-bank local population were more sensitive to the moisture of the environment, including anthropogenically transformed soil on the site. Similar conclusions were made in studying the relationship between leaf anatomy variations and local climatic conditions; it was found that an approach that focuses on the functional traits of plants can be an effective modeling tool for assessing the potential consequences of climate change impacts on plant communities (Küsteret al., 2011). These assumptions are consistent with the data (Zamin et al, 2013; Lindner et al., 2014) on the high level of influence of both rainfall and temperature on forest development.

Thus, the tendency for the increase in invasiveness, common to both local populations of alien species $U$. pumila, was found to differ in the nature of its manifestation due to the soil and microclimatic conditions of the given urbolandscape. The growth in the number of young plants of seed origin in the left-bank local population of Asiatic elm has positively correlated with the amount of precipitation during the vegetative period, together with an increase in air temperature relative to the climatic norm. With regard to the right-bank local population of $U$. pumila, we should expect an exponential growth in the number, provided that the current trends of climate change continue. Differences in the dynamics of two local populations of one species, located in different microclimatic and soil conditions, do not contradict the data of other authors. According to a report (Hanspach et al., 2010), generalized linear models created using data on the distribution of the European plant species and climatic parameters had different levels of reliability. 
The reason for this, according to the authors, was the dependence of the reliability of the model on the functional characteristics of plants, as well as the effect of ecology of the species.

At the same time, our study reflected the common problems that accompany the use of simple predictive models to assess the effects of global phenomena, and which are are inevitable at the moment. So, according to Prieto et al. (2009), extrapolation of the consequences of global climate change to plant phenology is fraught with difficulties and inaccuracies, since various combinations of environmental factors occur simultaneously. Hanspach et al. (2010) take a similar view, believing that when creating temporal or spatial predictions, uncertainty is inevitable, and prediction errors can depend not only on the quality of the data and on the modeling algorithm used, but also on the different characteristics of the species.

\section{Conclusion}

Local populations of Asiatic elm found during the route surveys had a seed origin, were at a considerable distance from the potential parent adult trees, and consisted of young virgin and generative plants. It has been established that the number of the young plants in the local populations has been steadily increasing during the last $10-15$ years, demonstrating the invasive nature of the alien species $U$. pumila. Mathematical models of the local population's dynamics in two different ecotopes confirm the increase in invasiveness of the alien species and predict the preservation of this trend in the subsequent period of development of local populations of $U$. pumila under the influence of climatic changes in the teppe Dnieper.

This work was carried out with the support of the State Fund for Fundamental Research of the Ministry of Education of Ukraine (Grant No. F76/103-2017).

\section{References}

Abramova, L. M. (2012). Expansion of invasive alien plant species in the republic of Bashkortostan, the Southern Urals: Analysis of causes and ecological consequences. Russian Journal of Ecology, 43(5), 352-357.

Bahuguna, R. N., \& Jagadish, K. S. V. (2015). Temperature regulation of plant phenological development. Environmental and Experimental Botany, 111, 83-90.

Baranova, O. G., \& Bralgina (Zyankina), E. N. (2015). Invazionnye vidy rastenij v tryoh gorodah Udmurtskoj Respubliki [Invasive plant species in three cities of Udmurt Republic]. Russian Journal of Biological Invasions, 4, 14-20 (in Russian).

Blackburn, T. M., Essl, F., Evans, T., Hulme, P. E., Jeschke, J. M., Kühn, I., Kumschick, S., Marková, Z., Mrugała, A., Nentwig, W., Pergl, J., Pyšek, P., Rabitsch, W., \& Bacher, S. (2014). A unified classification of alien species based on the magnitude of their environmental impacts. PloS Biology, 12(5), e1001850.

Borisova, E. A. (2016). Woody plant invasions into the Upper Volga natural communities. Russian Journal of Biological Invasions, 1, 24-30 (in Russian).

Burda, R. I. (2014). Evropeyskaya politika botanicheskih sadov po invazivnyim chuzherodnyim vidam [European policy of botanical gardens on invasive alien species]. Industrial Botany, 14, 3-14 (in Russian).

Chytrý, M., Pyšek, P., Wild, J., Pino, J., Maskell, L. C., \& Vilà, M. (2009). European map of alien plant invasions based on the quantitative assessment across habitats. Diversity and Distributions, 15(1), 98-107.

Copeland, L. O., \& McDonald, M. F. (2012). Principles of seed science and technology. Springer Science and Business Media.

de Lange, W. J., \& van Wilgen, B. W. (2010). An economic assessment of the contribution of biological control to the management of invasive alien plants and to the protection of ecosystem services in South Africa. Biological Invasions, 12(12), 4113-4124.

Dumalisile, L., \& Somers, M. J. (2017). The effects of an invasive alien plant (Chromolaena odorata) on large African mammals. Nature Conservation Research: Zapovednaâ Nauka, 2(4), 102-108.

Fateryga, V. V., \& Bagrikova, N. A. (2017). Invasion of Opuntia humifusa and O. phaeacantha (Cactaceae) into plant communities of the Karadag Nature Reserve. Nature Conservation Research: Zapovednaâ Nauka, 2(4), 26-39.

Foxcroft, L. C., Pyšek, P., Richardson, D. M., Genovesi, P., \& MacFadyen, S. (2017). Plant invasion science in protected areas: Progress and priorities. Biological Invasions, 19(5), 1353-1378.

Fuentes, N., Saldaña, A., Kühn, I., \& Klotz, S. (2015). Climatic and socioeconomic factors determine the level of invasion by alien plants in Chile. Plant Ecology and Diversity, 8(3), 371-377.
Gaertner, M., Wilson, J. R. U., Cadotte, M. W., Maclvor, J. S., Zenni, R. D., \& Richardson, D. M. (2017). Non-native species in urban environments: Patterns, processes, impacts and challenges. Biological Invasions, 19(12), 3461-3469.

Guzzetti, L., Galimberti, A., Bruni, I., Magoni, C., Ferri, M., Tassoni, A., Sangiovanni, E., Agli, M. D., \& Labra, M. (2017). Bioprospecting on invasive plant species to prevent seed dispersal. Scientific Reports, 7, 13799.

Hanspach, J., Kühn, I., Pompe, S., \& Klotz, S. (2010). Predictive performance of plant species distribution models depends on species traits. Perspectives in Plant Ecology, Evolution and Systematics, 12(3), 219-225.

Hou, Q. Q., Chen, B. M., Peng, S.-L., \& Chen, L.-Y. (2014). Effects of extreme temperature on seedling establishment of nonnative invasive plants. Biological Invasions, 16(10), 2049-2061.

Kowarik, I., \& Pyšek, P. (2012). The first steps towards unifying concepts in invasion ecology were made one hundred years ago: Revisiting the work of the Swiss botanist Albert Thellung. Diversity and Distributions, 18(12), 1243-1252.

Küster, E. C., Bierman, S. M., Klotz, S., \& Kühn, I. (2011). Modelling the impact of climate and land use change on the geographical distribution of leaf anatomy in a temperate flora. Ecography, 34(3), 507-518.

Lindner, M., Fitzgerald, J. B., Zimmermann, N. E., Reyer, C., Delzon, S., van der Maaten, E., Schelhaas, M.-J., Lasch, P., Eggers, J., der Maaten-Theunissen, M., Suckow, F., Psomas, A., Poulter, B., \& Hanewinkel, M. (2014). Climate change and European forests: What do we know, what are the uncertainties, and what are the implications for forest management? Journal of Environmental Management, 146, 69-83.

Lockwood, J. L., Hoopes, M. F., \& Marchetti, M. P. (2007). Invasion Ecology. Blackwell Publishing, Malden (Massachusetts).

Lykholat, T., Lykholat, O., \& Antonyuk, S. (2016). Immunohistochemical and biochemical analysis of mammary gland tumours of different age patients. Cytology and Genetic, 50(1), 32-41.

Lykholat, Y. V., Khromykh, N. A., Ivan’ko, I. A., Matyukha, V. L., Kravets, S. S., Didur, O. O., Alexeyeva, A. A., \& Shupranova, L. V. (2017). Otsinka i prohnoz invaziinosti deiakykh adventyvnykh roslyn za vplyvu klimatychnykh zmin u Stepovomu Prydniprovi [Assessment and prediction of the invasiveness of some alien plants in conditions of climate change in the steppe Dnieper region]. Biosystems Diversity, 25(1), 52-59.

Lykholat, Y. V., Khromykh, N., Ivanko, I., Kovalenko, I., Shupranova, L., \& Kharytonov, M. (2016a). Metabolic responses of steppe forest trees to altitude-associated local environmental changes. Agriculture and Forestry, 62(2), 163-171.

Lykholat, Y., Alekseeva, A., Khromykh, N., Ivan'ko, I., Kharytonov, M., \& Kovalenko, I. (2016b). Assessment and prediction of viability and metabolic activity of Tilia platyphyllos in arid steppe climate of Ukraine. Agriculture and Forestry, 62(3), 55-64.

Marbuah, G., Gren, I.-M., \& McKie, B. (2014). Economics of harmful invasive species: A review. Diversity, 6(3), 500-523.

Maslyakov, V. Y., \& Izhevsky, S. S. (2011). Invazii rastitelnoyadnyh nasekomyh $\mathrm{v}$ evropeyskoj chasti Rossii [Alien phytophagous insects invasions in the European Part of Russia]. IGRAS, Moscow (in Russian).

Mech, A. M., Tobin, P. C., Teskey, R. O., Rhea, J. R., \& Gandhi, K. J. K. (2018). Increases in summer temperatures decrease the survival of an invasive forest insect. Biological Invasions, 20(2), 365-374.

Nazarenko, M., Lykholat, Y., Grigoryuk, I., \& Khromykh, N. (2018). Optimal doses and concentrations of mutagens for winter wheat breeding purposes. Part I. Grain productivity. Joumal of Central European Agriculture, 19(1), 194-205.

Olson, L. J. (2006). The economics of terrestrial invasive species: A review of the literature. Agricultural and Resource Economics Review, 35(1), 178-194.

Pimentel, D., Zuniga, R., \& Morrison, D. (2005). Update on the environmental and economic costs associated with alien-invasive species in the United States. Ecological Economics, 52(3), 273-288.

Pismarkina, E. V., \& Silaeva, T. B. (2018). Osobennosti naturalizatsii chuzherodnyh rastenij na severo-zapade Privolzhskoj vozvyshennosti [Features of naturalization of alien plants in the North-West of Privolzhskaya Uplands]. Journal of Biological Invasions, 1, 88-102 (in Russian).

Pratt, C. F., Constantine, K. L., \& Murphy, S. T. (2017). Economic impacts of invasive alien species on African smallholder livelihoods. Global Food Security, 14, 31-37.

Prieto, P., Penuelas, J., Niinemets, Ü., Ogaya, R., Schmidt, I. K., Beier, C., Tietema, A., Sowerby, A., Emmett, B. A., Láng, E. K., Kröel-Dulay, G., Lhotsky, B., Cesaraccio, C., Pellizzaro, G., De Dato, G., Sirca, C., \& Estiarte M. (2009). Changes in the onset of spring growth in shrubland species in response to experimental warming along a north-south gradient tin Europe. Global Ecology and Biogeography, 18(4), 473-484.

Pyšek, P., \& Richardson, D. M. (2006). The biogeography of naturalization in alien plants. Journal of Biogeography, 33(12), 2040-2050.

Pyšek, P., Jarošík, V., Hulme, P. E., Pergl, J., Hejda, M., Schaffner, U., \& Vilà, M. (2012). A global assessment of invasive plant impacts on resident species, communities and ecosystems: The interaction of impact measures, invading species’ traits and environment. Global Change Biology, 18(5), 1725-1737. 
Richardson, D. M., \& Rejmánek, M. (2011). Trees and shrubs as invasive alien species - a global review. Diversity and Distributions, 17(5), 788-809.

Rouget, M., Robertson, M. P., Wilson, J. R. U., Hui, C., Essl, F., Renteria, J. L., \& Richardson, D. M. (2016). Invasion debt - quantifying future biological invasions. Diversity and Distributions, 22(4), 445-456.

Sperlich, D., Chang, C. T., Peñuelas, J., Gracia, C., \& Sabaté, S. (2015). Seasonal variability of foliar photosynthetic and morphological traits and drought impacts in a Mediterranean mixed forest. Tree Physiology, 35(5), 501-520.

Trentanovi, G., von der Lippe, M., Sitzia, T., Ziechmann, U., Kowarik, I., \& Cierjacks, A. (2013). Biotic homogenization at the community scale: Disentangling the roles of urbanization and plant invasion. Diversity and Distributions, 19(7), 738-748.

van Wilgen, B., Richardson, D., Le Maitre, D., Marais, C., \& Magadlela, D. (2001). Environment, development and sustainability, 3(2), 145-168.

Vilà, M., Espinar, J. L., Hejda, M., Hulme, P. E., Jarošík, V., Maron, J. L., Pergl, J., Schaffner, U., Sun, Y., \& Pyšek, P. (2011). Ecological impacts of invasive alien plants: A meta-analysis of their effects on species, communities and ecosystems. Ecology Letters, 14(7), 702-708.
Wagner, V., Chytrý, M., Jiménez-Alfaro, B., Pergl, J., Hennekens, S., Biurrun, I., Knollová, I., Berg, C., Vassilev, K., Rodwell, J. S., Škvorc, Ž., Jandt, U., Ewald, J., Jansen, F., Tsiripidis, I., Botta-Dukát, Z., Casella, L., Attorre, F., Rašomavičius, V., Ćušterevska, R., Schaminée, J. H. J., Brunet, J., Lenoir, J., Svenning, J.-C., Kącki, Z., Petrášová-Šibíková, M., Šilc, U., García-Mijangos, I., Campos, J. A., Fernández-González, F., Wohlgemuth, T., Onyshchenko, V., \& Pyšek, P. (2017). Alien plant invasions in European woodlands. Diversity and Distributions, 23(9), 969-981.

Walther, G.-R., Roques, A., Hulme, P. E., Sykes, M. T., Pyšek, P., Kuhn, I., Zobel, M., Bacher, S., Botta-Dukát, Z., Bugmann, H., Czúcz, B., Dauber, J., Hickler, T., Jarosík, V., Kenis, M., Klotz, S., Minchin, D., Moora, M., Nentwig, W., Ott, J., Panov, V. E., Reineking, B., Robinet, C., Semenchenko, V., Solarz, W., Thuiller, W., Vilà, M., Vohland, K., \& Settele, J. (2009). Alien species in a warmer world: Risks and opportunities. Trends in Ecology and Evolution, 24(12), 686-693.

Zamin, N. T., Machado do Amaral, S., Filho, A. F., \& Koehler, H. S. (2013). Effect of climate variables on monthly growth in modeling biological yield of Araucaria angustifolia and pinus taeda in the juvenile phase. International Journal of Forestry Research, 2013, Article ID 646759. 